\title{
Zircon U-Pb and Molybdenite Re-Os Dating of Gangjiang Porphyry Cu-Mo Deposit in Nimu Ore Belt, Southern Tibet, China and Its Geological Significance
}

\author{
Hua Jiang ${ }^{1,2, ~ a, ~ W e n c h a n g ~} \mathrm{Li}^{1, \mathrm{~b}}$ \\ ${ }^{1}$ The Faculty of Land Resource Engineering Kunming University of Science and Technology, No. \\ 121 Wenchang Road, Kunming City, Yunnan Province, China \\ ${ }^{2}$ The Yunnan Copper Group mineral resources department room 722\#, No. 111 of Renmin East \\ Road Kunming City, Yunnan Province, China \\ ajh@yunnancopper.com, bliwenchang@126.com
}

Keywords: zircon U-Pb; molybdenite Re-Os dating; Nimu Ore Belt; Gangjiang Porphyry Cu-Mo Deposit; geological Significance

\begin{abstract}
In order to determine the ages of magmatism and mineralization, and thus to disentangle the complicated magmatic evolution and the relationship between magmatic process and copper-molybdenum mineralization, the authors carried out a study of LA-ICP-MS zircon U-Pb dating of monzonite granite porphyry, granodiorite porphyry, quartz-mica diorite porphyrite in Gangjiang porphyry $\mathrm{Cu}-\mathrm{Mo}$ deposit, corresponding with zircon $\mathrm{U}-\mathrm{Pb}$ ages of $16.6 \pm 0.3 \mathrm{Ma}$, $16.1 \pm 0.2 \mathrm{Ma}$, and $14.4 \pm 0.4 \mathrm{Ma}$. Meanwhile, twelve molybdenite samples separated from quartz sulfides veins in Gangjiang copper orebodies were used for Re-Os dating; the model ages obtained range from $13.24 \pm 0.20 \mathrm{Ma}$ to $13.55 \pm 0.22 \mathrm{Ma}$, with weighted average $13.4 \pm 0.1 \mathrm{Ma}$ and isochron age 13.6 $\pm 1.6 \mathrm{Ma}$. To combine our study results, field geological survey and previous research data, it is proposed that the intrusion sequence is ore-bearing monzonite granite porphyry $\rightarrow$ granodiorite porphyry $\rightarrow$ rhyolite porphyry (depth named as quartz-mica diorite porphyrite), the porphyry intrusion occurred range from $16.6 \mathrm{Ma}$ to $14.4 \mathrm{Ma}$, and the mineralization age of Gangjiang porphyry $\mathrm{Cu}-\mathrm{Mo}$ deposit is about $13.4 \mathrm{Ma}$, so the porphyritic granodiorite could responsible for the mineralization and related alteration. Diagenesis and mineralization is a continuous process of magmatic evolution. Gangjiang porphyry $\mathrm{Cu}-\mathrm{Mo}$ deposit was formed in post-collisional extension setting of India-Asia continental collision orogenic belt during the Miocene.
\end{abstract}

\section{Introduction}

The Gangjiang porphyry $\mathrm{Cu}-\mathrm{Mo}$ deposit is one of the deposits in Nimu ore belt and located in the middle of the Gangdise metallogenic belt, Southern Tibet, China. The Nimu copper molybdenum ore belt is consisted of Tinggong copper-molybdenum deposit, Chongjiang copper-molybdenum deposit, Bairong copper-molybdenum deposit and several copper-molybdenum mineral prospects.

The Gangjiang deposit is discovered during the $1: 1$ million and $1: 200,000$ regional soil geochemical surveyin the 1980s, and then the Geological Survey of Tibet conducted following detail geochemical survey to confirm the economic potential of the deposit. However, due to harsh environment and poor access to working area, the degree of deposit research is relatively low. the Gangjiang deposit had not been neither well explored and studied in early time. After the Yunnan Copper Group Lhasa Tianli Company and Sichuan Metallurgical and Geological Exploration Institute involving into the exploration in the area, relevant study was carried out. Based on field observation and analyzing the ages of intrusions, including monzonite granite porphyry, porphyritic quartz-mica diorite and porphyritic granodiorite and related ores with LA-ICP-MS (Laser Ablation Multicollector inductively Coupled Plasma Mass Spectrometry) zircon U-Pb dating and molybdenite Re-Os method, the study aim to understand the complicated magmatic history, ore forming process and source of metals; Moreover, to research-temporal evolution and spatial 
distribution of the same type of ore deposits in the area will help to establish intrusions and ore-forming age framework of Gangdise metallogenic belt at post-collisional extension stage the and gives a brief overview of metallogenic dynamics of the deposit.

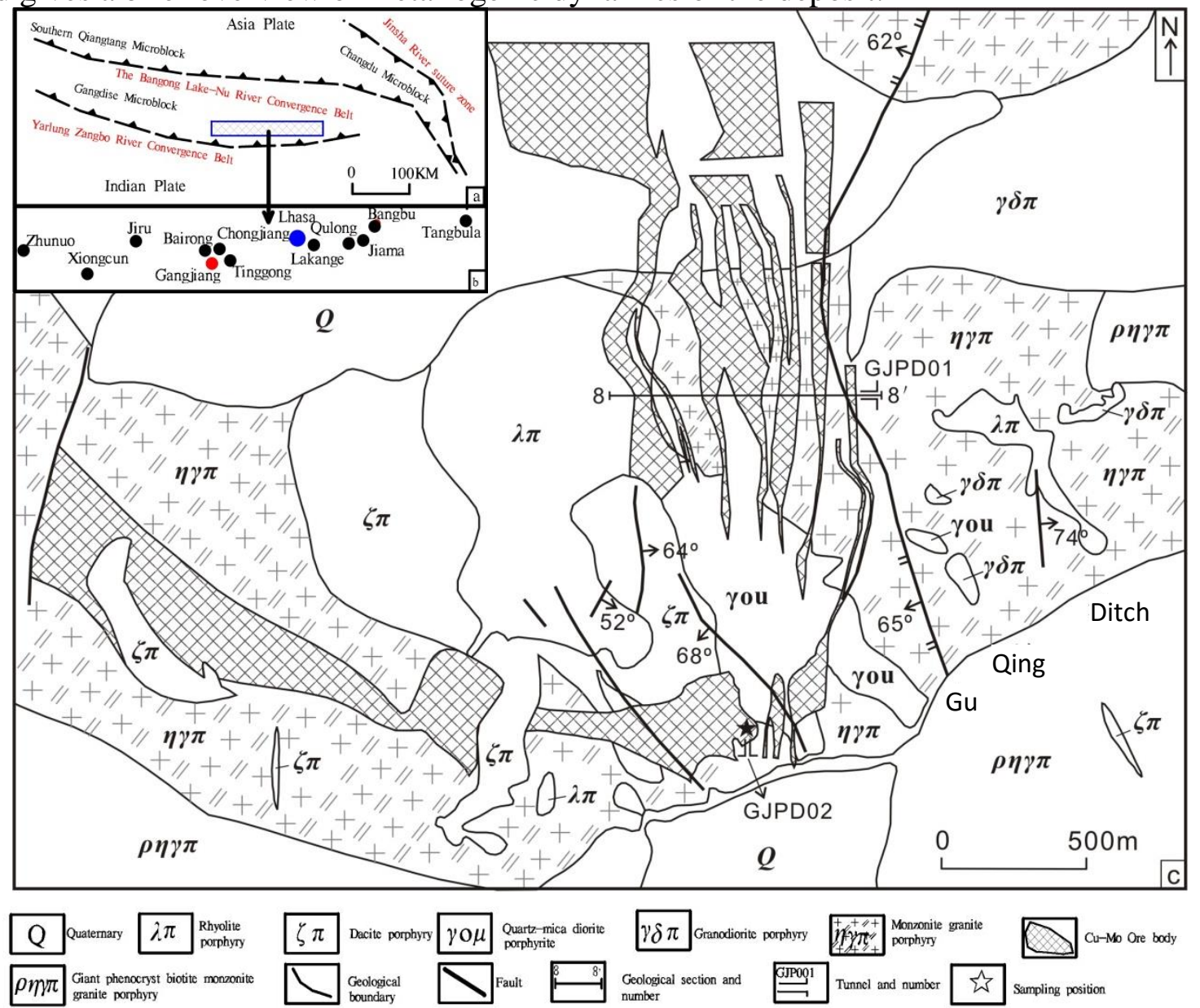

Fig.1 Tectonic location of the Gangdese metallogenic belt (a), the distribution of main porphyry deposits (b), geological sketch of Gangjiang mining area $(\mathrm{c})^{[1][2][3]}$

\section{LA-ICP-MS Zircon U-Pb Dating}

2.1 Sample Description. The samples used for zircon U-Pb dating were collected from the drill core in the Gangjiang deposit. The sample includes fresh monzonite granite porphyry, eight granodiorite porphyry, and nine quartz-mica diorite porphyrite examples. The petrographic characteristics of the three types of rocks are as follows: (1)monzonite granite porphyry (No. A5508-1) is light gray with massive and porphyritic structure (Fig. 2a, d). (2)The granodiorite porphyry (No. A5508-2) is dark gray with massive and multi-plaque structure (Figure 2b, e). (Fig. 2c, f). (3) The quartz-mica diorite porphyrite (No. A5508-3) is gray - gray and dark gray with massive and, porphyritic structure (Fig. 2C, f).

Table1 the collection location list of zircon U-Pb dating sample in Gangjiang copper-molybdenum deposit

\begin{tabular}{cccccc}
\hline \multicolumn{2}{c}{$\begin{array}{c}\text { Monzonite granite porphyry } \\
\text { (8 in total) }\end{array}$} & \multicolumn{2}{c}{$\begin{array}{c}\text { Granodiorite porphyry } \\
\text { (8 in total) }\end{array}$} & $\begin{array}{c}\text { Quartz-mica diorite porphyrite } \\
(8 \text { in total) }\end{array}$ \\
\hline ZKW0800-410m & ZK2411-512m & DZK1201-431m & QZK301-520m & ZK1604-425m & ZK2006-430m \\
ZK2411-512m & ZK807-140m & ZKN812-424m & BZK1514-425m & ZK802-81m & GJ18-84m \\
ZK2003-25m & ZK805-97m & ZK807-111m & ZK807-133m & ZK805-77m & GJ21-22m \\
ZK803-120m & ZK807-114m & ZK1204-102m & ZK1204-115m & ZK2005-49m & GJ15-95m \\
& & & & ZK1204-119m & \\
\hline
\end{tabular}




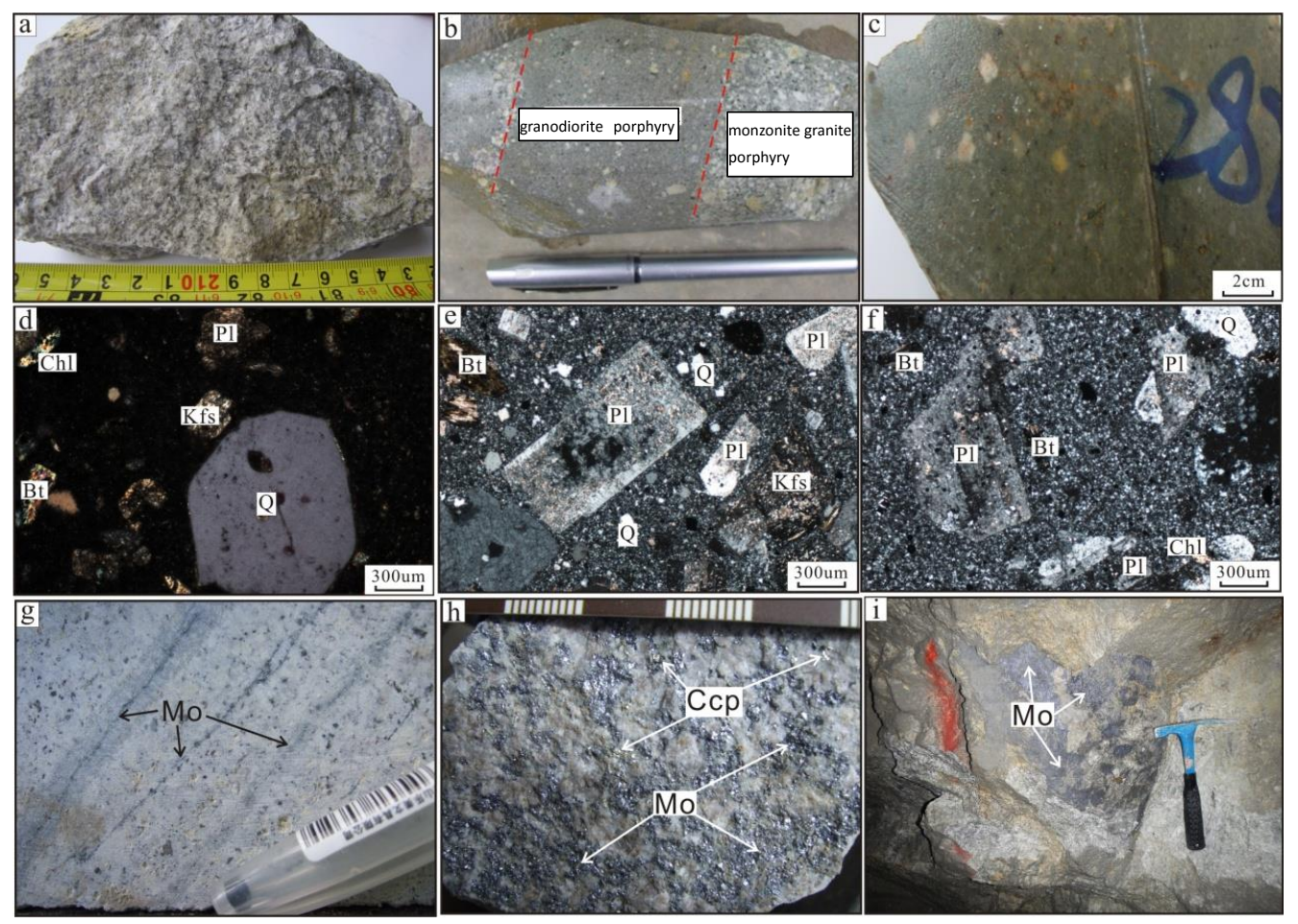

Fig.2 Photographs of hand specimens (a, b, c, g, h, i) and outcrops of Gangjiang copper-molybdenum deposit; Photomicrographs of samples from Gangjiang copper-molybdenum deposit(a.sample of the monzonite granite porphyry; b.sample of the granodiorite porphyry; $c$. sample of the quartz-mica diorite porphyrite; d. micrograph of the monzonite granite porphyry; e. Micrograph of granodiorite porphyry; f. Micrograph of the quartz-mica diorite porphyrite; g. Fine vein molybdenite mineralization; h Fine vein-like molybdenum mineralization cross section; i.Mine sampling location. Minerals Abbreviations: Bt.Biotite; Chl.Chlorite; Kfs.Potassium feldspar;Pl. Plagioclase; Q.Quartz; Ccp. Chalcopyrite; Mo. Molybdenite)

2.2 Analytical Method. Sample crushing, zircon sorting, cathode uminescence (CL) imaging were completed in Langfang, Hebei Province Institute of Geology and Mineral Resources Research Laboratory. Laser ablation LA-ICP-MS zircon U-Pb isotope analysis was carried out in the Australian Mineral Laboratory, and the analytical principles and procedures are described in the literature ${ }^{[4][5][6]}$. The analysis instrumentations were a HR ICP-MS mass spectrometer and a New Wave Research excimer laser ablation system. International standard zircon 91500 was used as a reference standard for calibration and controlling the conditions of analytical instrumentation the United States National Bureau of Standards Bureau of synthetic silicate glass NIST SRM610 was applied asexternal standard. ${ }^{29} \mathrm{Si}$ was used as athe internal standard for alibration of data. The elemental and isotopic ratios and age calculations for zircons were performed at ICPMS DataCal ${ }^{[7]}$. Zircon U-Pb harmonic plot and weighted mean age calculations were performed on the ISOPLOT software ${ }^{[8][9]}$.

2.3 Zircon U-Pb Dating Results. Eleven analyses were carried out on the zircon grains from monzonite granite porphyry. A total of fifteen analyses were conducted on twelve zircon from granodiorite porphyry. Thirteen analyses were completed in ten zircon from quartz diorite. The zircon $\mathrm{U}-\mathrm{Pb}$ isotope test results are shown in Table 2. The zircon cathode luminescence (CL) images and measured point with corresponding ${ }^{206} \mathrm{~Pb} /{ }^{238} \mathrm{U}$ ages are shown in Fig. 3.The Zircon ${ }^{207} \mathrm{~Pb} /{ }^{235} \mathrm{U}-{ }^{206} \mathrm{~Pb} /{ }^{238} \mathrm{U}$ harmonic diagram shown in Figure 4.

The ${ }^{206} \mathrm{~Pb} /{ }^{238} \mathrm{U}$ ages of the monzonite granite porphyry (A5508-1) can be divided into three groups: old, middle and young. The maximum age of point 4.1 is $32.4 \mathrm{Ma}$, The nucleus is the core of inheriting magmatic nucleus, and the shape is round, the color is deeper than the edge, and the edge of zircon is ambiguous, which could reflect remelting. Points 2.1, 5.1 and 10.1 give ages of 
20.2Ma, 20.0Ma and 20.0Ma respectively, and the projection points were obviously deviated from the concordia curve. 8.1 point shot on the edge of zircon grain and the result shows strong contamination so it should not be used on weighted average calculation. The rest of analyses points are located on the concordia and nearby, and have ages range from 17.9 to 15.1Ma Basically no lead loss or gain has been identified, then U-Pb system should remain closed ${ }^{[10]}$, The weighted mean age of zircon ${ }^{206} \mathrm{~Pb} /{ }^{238} \mathrm{U}$ data is $16.6 \pm 0.3 \mathrm{Ma}(\mathrm{MSWD}=0.94)$,

The ages of the granodiorite porphyry (A5508-2) are obviously older than the others two units (6.18), and the projection is located on the concordia curve (8.2 and 10.1). The weighted mean age of zircon ${ }^{206} \mathrm{~Pb} /{ }^{238} \mathrm{U}$ data from granodiorite porphyry is $16.1 \pm 0.2 \mathrm{Ma}$, MSWD $=1.07$.

The ages of quartz-mica diorite (analysis points 2.1, 3.1, 3.2, 4.1, 5.1 and 8.1) were significantly older than other ages from quartz-mica diorite, so these ages are consider nvalid data (Table 3). The ages from seven other effective analysis points values varied from 16.3 to $13.1 \mathrm{Ma}$, and calculated the weighted average age is $14.4+0.4 \mathrm{Ma}(\mathrm{MSWD}=1.12)$.

Table 2 LA-ICP-MS zircon U-Pb dating results of rocks in Gangjiang copper-molybdenum deposit

\begin{tabular}{|c|c|c|c|c|c|c|c|c|}
\hline \multirow{2}{*}{$\begin{array}{l}\text { Testing } \\
\text { points }\end{array}$} & \multicolumn{5}{|c|}{ Isotope ratio } & \multirow[b]{2}{*}{ $\pm \%$} & \multicolumn{2}{|c|}{ Age（Ma） } \\
\hline & ${ }^{207} \mathrm{~Pb} /{ }^{206} \mathrm{~Pb}$ & $\pm \%$ & ${ }^{207} \mathrm{~Pb} /{ }^{235} \mathrm{U}$ & $\pm \%$ & ${ }^{206} \mathrm{~Pb} /{ }^{238} \mathrm{U}$ & & ${ }^{206} \mathrm{~Pb} /{ }^{238} \mathrm{U}$ & $\pm 1 \sigma$ \\
\hline \multicolumn{9}{|c|}{ A5508-1 (Monzonite granite porphyry) } \\
\hline 1.1 & 0.0556 & 18.53 & 0.0170 & 16.12 & 0.0023 & 11.91 & 15.1 & 1.6 \\
\hline 1.2 & 0.0613 & 48.51 & 0.0216 & 56.52 & 0.0026 & 18.12 & 16.7 & 0.2 \\
\hline 2.1 & 0.0964 & 69.04 & 0.0395 & 72.72 & 0.0031 & 29.09 & 20.2 & 1.2 \\
\hline 2.2 & 0.1270 & 73.80 & 0.0410 & 92.32 & 0.0026 & 14.60 & 16.4 & 0.3 \\
\hline 3.1 & 0.0573 & 34.65 & 0.0199 & 31.77 & 0.0028 & 34.06 & 17.8 & 1.1 \\
\hline 4.1 & 0.0513 & 18.03 & 0.0333 & 23.00 & 0.0050 & 17.96 & 32.4 & 2.0 \\
\hline 5.1 & 0.1379 & 39.88 & 0.0570 & 36.88 & 0.0031 & 20.14 & 20.0 & 1.3 \\
\hline 5.2 & 0.0581 & 36.35 & 0.0192 & 35.71 & 0.0025 & 13.39 & 15.9 & 0.7 \\
\hline 6.1 & 0.0684 & 47.13 & 0.0242 & 53.65 & 0.0027 & 31.89 & 17.1 & 0.4 \\
\hline 7.1 & 0.1499 & 47.62 & 0.0566 & 54.85 & 0.0028 & 11.81 & 17.9 & 1.2 \\
\hline 8.1 & 0.1036 & 46.09 & 0.0396 & 54.65 & 0.0029 & 25.36 & 18.4 & 1.7 \\
\hline 8.2 & 0.0502 & 30.84 & 0.0163 & 30.06 & 0.0025 & 19.64 & 16.2 & 0.5 \\
\hline 9.1 & 0.0633 & 44.20 & 0.0215 & 50.43 & 0.0025 & 18.89 & 16.2 & 0.5 \\
\hline 10.1 & 0.1933 & 57.63 & 0.0897 & 94.92 & 0.0031 & 28.31 & 20.0 & 1.4 \\
\hline 11.1 & 0.0484 & 39.74 & 0.0162 & 40.86 & 0.0025 & 11.75 & 16.1 & 0.6 \\
\hline \multicolumn{9}{|c|}{ A5508-2 (Granodiorite porphyry) } \\
\hline 1.1 & 0.0559 & 31.52 & 0.0197 & 29.17 & 0.0026 & 21.33 & 16.9 & 0.7 \\
\hline 2.1 & 0.0665 & 61.17 & 0.0247 & 73.83 & 0.0026 & 13.62 & 16.9 & 0.8 \\
\hline 3.1 & 0.0638 & 15.21 & 0.0190 & 24.30 & 0.0023 & 26.64 & 14.9 & 1.2 \\
\hline 4.1 & 0.0545 & 27.50 & 0.0188 & 29.95 & 0.0026 & 14.88 & 16.7 & 0.4 \\
\hline 5.1 & 0.0653 & 42.44 & 0.0226 & 50.15 & 0.0025 & 20.35 & 16.0 & 0.2 \\
\hline 5.2 & 0.0643 & 51.95 & 0.0235 & 52.82 & 0.0027 & 15.37 & 17.2 & 1.1 \\
\hline 6.1 & 0.0538 & 26.90 & 0.0239 & 23.02 & 0.0034 & 21.31 & 21.8 & 1.2 \\
\hline 7.1 & 0.0519 & 38.19 & 0.0169 & 39.80 & 0.0024 & 24.69 & 15.6 & 0.6 \\
\hline 8.1 & 0.0765 & 60.94 & 0.0256 & 49.16 & 0.0026 & 24.19 & 16.6 & 0.5 \\
\hline 8.2 & 0.0939 & 31.28 & 0.03161 & 31.92 & 0.0026 & 30.23 & 17.1 & 1.0 \\
\hline 9.1 & 0.0718 & 17.57 & 0.0202 & 18.57 & 0.0022 & 10.10 & 14.2 & 1.9 \\
\hline 10.1 & 0.0951 & 44.87 & 0.0356 & 47.26 & 0.0028 & 22.77 & 17.8 & 1.5 \\
\hline 10.2 & 0.0645 & 20.73 & 0.0207 & 16.25 & 0.0025 & 13.34 & 16.0 & 0.2 \\
\hline 11.1 & 0.0683 & 33.06 & 0.0204 & 30.32 & 0.0023 & 14.77 & 15.0 & 1.1 \\
\hline 12.1 & 0.0552 & 23.83 & 0.0168 & 22.83 & 0.0024 & 15.99 & 15.3 & 0.8 \\
\hline \multicolumn{9}{|c|}{ A5508-3 (Quartz-mica diorite porphyrite) } \\
\hline 1.1 & 0.0859 & 62.46 & 0.0274 & 72.79 & 0.0024 & 12.68 & 15.1 & 0.2 \\
\hline
\end{tabular}




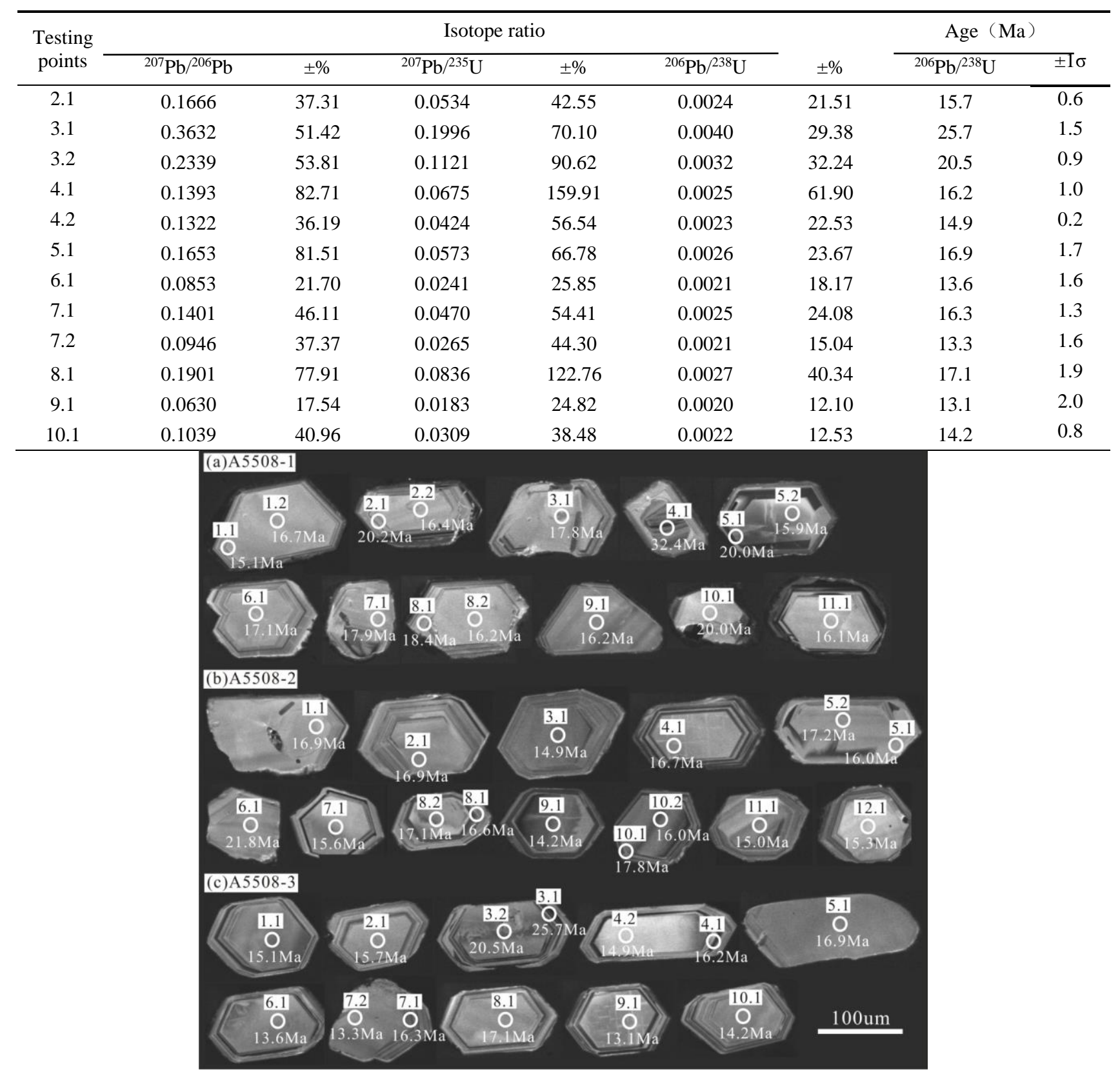

Fig. $3 \mathrm{CL}$ images of zircons from monzogranite (a), granodiorite (b) and tonolity (c) in Gangjiang
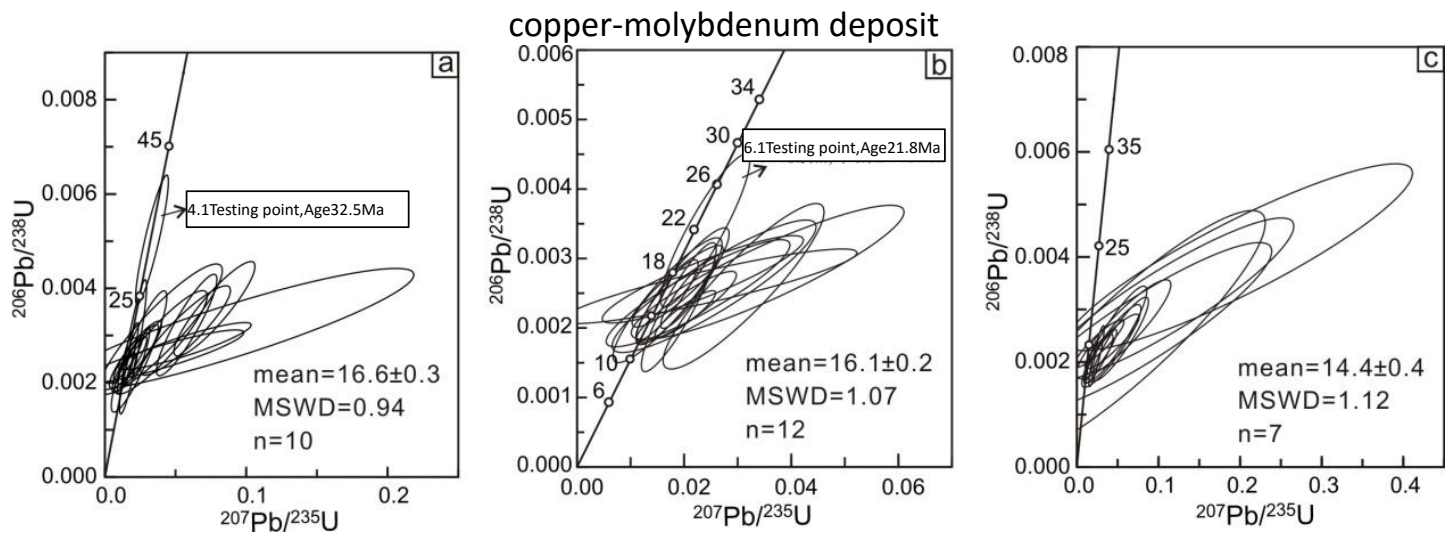

Fig. 4 Zircon U-Pb concoria diagram from monzogranite (a), granodiorite (b) and tonolity (c) in Gangjiang copper-molybdenum deposit 


\section{Molybdenite Re-Os isotope Dating}

3.1 Sample Collection and Testing. Twelve molybdenite samples were collected from a location $101 \mathrm{~m}$ of the GJPD02 tunnel (Fig. 1, Fig. 3i). The sample numbers are BSPD2-03-1 BSPD2-03-12. Those molybdenite samples are hosted in the veinlets of two feldspar porphyritic granite, Notably, there is disseminated chalcopyrite distributed around the molybdenite veins (Fig. $2 g, h$ ).

The molybdenite Re-Os isotope analysis of was completed by the National Geological Experimental Test Center, China. The molybdenite samples with purity of $99 \%$ are obtained by manual selection, grinding and microscopic removal. The samples are decomposed by Carius tube, The isotope ratios of Re and Os were determined by inductively coupled plasma mass spectrometry (TJA X-series ICP-MS). The Re level of JDC was $0.00021 \pm 0.0002 \mathrm{ng} / \mathrm{g}, 0.00010 \pm 0.00002 \mathrm{ng} /$ $\mathrm{g}$ and $0.00021 \pm 0.00006 \mathrm{ng} / \mathrm{g}$ for Os and ${ }^{187} \mathrm{Os}$, and the Re content of the standard sample JDC was $(17.22 \pm 0.14) \mathrm{ug} / \mathrm{g}$ and the Os content was $(25.23 \pm 0.17) \mathrm{ng} / \mathrm{g}$, which were consistent with the recommended values, which confirmed that the age data obtained in this study were accurate and reliable. The model age $t$ can be calculated from the content of ${ }^{187} \mathrm{Re}$ and ${ }^{187} \mathrm{Os}$. The formula is: $\mathrm{t}=\left[\ln \left(1+{ }^{187} \mathrm{Os} /{ }^{187} \mathrm{Re}\right)\right] / \lambda$, where $\lambda(187 \mathrm{Re}$ decay constant $)=1.666 \times 10-11 \mathrm{a}-1$.

3.2 Molybdenite Re-Os Analysis Results. The Re-Os isotopie result of twelve molybdenite samples from Gangjiang porphyry copper-molybdenum deposit are shown in Table 3 . The general Os content in molybdenite is very low and tends to 0 , indicating that the ${ }^{187} \mathrm{Os}$ are almost completely decayed from ${ }^{187} \mathrm{Re}$, which is in accordance with the Re-Os isotope system model age. The change of the content of Re in molybdenite $(155.4+1.1) \mathrm{ug} / \mathrm{g} \sim(171.1+1.5) \mathrm{ug} / \mathrm{g}$, average $162.9 \mathrm{ug} / \mathrm{g},{ }^{187} \mathrm{Re}$ content is coordinated with the change of ${ }^{187} \mathrm{Os}$ content.

The ages range from $13.2 \pm 0.20 \mathrm{Ma}$ to $13.55 \pm 0.22 \mathrm{Ma}$, and the weighted average age is $13.4 \pm$ $0.1 \mathrm{Ma}(\mathrm{MSWD}=0.65$ ) (Fig.5b). Using the ISOPLOT software of the twelve groups of isochron age data fitting ${ }^{[8]}$,the testing obtain a better ${ }^{187} \mathrm{Re}^{187}$ Os isochron slope according to the calculated isochron age of $13.6+1.6 \mathrm{Ma}, \mathrm{MSWD}=1.2$ (Figure 5a).

The the model age is similar to that in the error range, indicating the reliability of the test data. By field observation, the Gangjiang $\mathrm{Cu}-\mathrm{Mo}$ deposit was mainly developed in monzonite granite porphyry with stock work and chalcopyrite. Therefore, the formation age dating of molybdenite Re-Os isotope have basically represent the Gangjiang copper-molybdenum deposit, metallogenic event occurred in the Miocene.

Table 3 Re-Os isotopic data of molybdenites from Gangjiang Cu-Mo deposit

\begin{tabular}{ccccccc}
\hline \multirow{2}{*}{$\begin{array}{c}\text { Sample } \\
\text { number }\end{array}$} & $\begin{array}{c}\text { Sample } \\
\text { weight }\end{array}$ & $\mathrm{Re} \pm 2 \sigma$ & $\mathrm{Os} \pm 2 \sigma$ & ${ }^{187} \mathrm{Re} \pm 2 \sigma$ & ${ }^{187} \mathrm{Os} \pm 2 \sigma$ & Model age \\
\cline { 2 - 7 } & $\mathrm{g}$ & $\mathrm{ug} / \mathrm{g}$ & $\mathrm{ng} / \mathrm{g}$ & $\mathrm{ug} / \mathrm{g}$ & $\mathrm{ng} / \mathrm{g}$ & $\mathrm{Ma}$ \\
\hline BSPD2-03-1 & 0.00504 & $161.3 \pm 1.4$ & $0.0016 \pm 0.0371$ & $101.4 \pm 0.9$ & $22.38 \pm 0.17$ & $13.24 \pm 0.20$ \\
BSPD2-03-2 & 0.01006 & $163.8 \pm 1.8$ & $0.0652 \pm 0.0184$ & $102.9 \pm 1.1$ & $23.23 \pm 0.14$ & $13.55 \pm 0.22$ \\
BSPD2-03-3 & 0.01053 & $165.0 \pm 2.0$ & $0.1152 \pm 0.0253$ & $103.7 \pm 1.2$ & $23.22 \pm 0.17$ & $13.44 \pm 0.23$ \\
BSPD2-03-4 & 0.01028 & $161.0 \pm 1.4$ & $0.0008 \pm 0.0502$ & $101.2 \pm 0.9$ & $22.81 \pm 0.13$ & $13.52 \pm 0.19$ \\
BSPD2-03-5 & 0.01044 & $155.9 \pm 1.3$ & $0.0915 \pm 0.0178$ & $98.0 \pm 0.8$ & $21.92 \pm 0.16$ & $13.42 \pm 0.20$ \\
BSPD2-03-6 & 0.01018 & $165.0 \pm 1.4$ & $0.1051 \pm 0.033$ & $103.7 \pm 0.9$ & $23.16 \pm 0.15$ & $13.41 \pm 0.19$ \\
BSPD2-03-7 & 0.01038 & $171.1 \pm 1.5$ & $0.1059 \pm 0.0253$ & $107.6 \pm 0.9$ & $23.95 \pm 0.14$ & $13.36 \pm 0.19$ \\
BSPD2-03-8 & 0.01036 & $164.8 \pm 1.4$ & $0.1108 \pm 0.0182$ & $103.6 \pm 0.9$ & $23.08 \pm 0.16$ & $13.38 \pm 0.20$ \\
BSPD2-03-9 & 0.01007 & $165.8 \pm 1.3$ & $0.0928 \pm 0.0184$ & $104.2 \pm 0.8$ & $23.18 \pm 0.14$ & $13.35 \pm 0.19$ \\
BSPD2-03-10 & 0.01096 & $162.5 \pm 1.3$ & $0.0007 \pm 0.1199$ & $102.2 \pm 0.8$ & $22.72 \pm 0.16$ & $13.35 \pm 0.19$ \\
BSPD2-03-11 & 0.01036 & $155.4 \pm 1.1$ & $0.0604 \pm 0.026$ & $97.7 \pm 0.7$ & $21.75 \pm 0.16$ & $13.36 \pm 0.19$ \\
BSPD2-03-12 & 0.01073 & $162.9 \pm 1.2$ & $0.0924 \pm 0.0252$ & $102.4 \pm 0.8$ & $22.79 \pm 0.22$ & $13.36 \pm 0.21$ \\
\hline
\end{tabular}




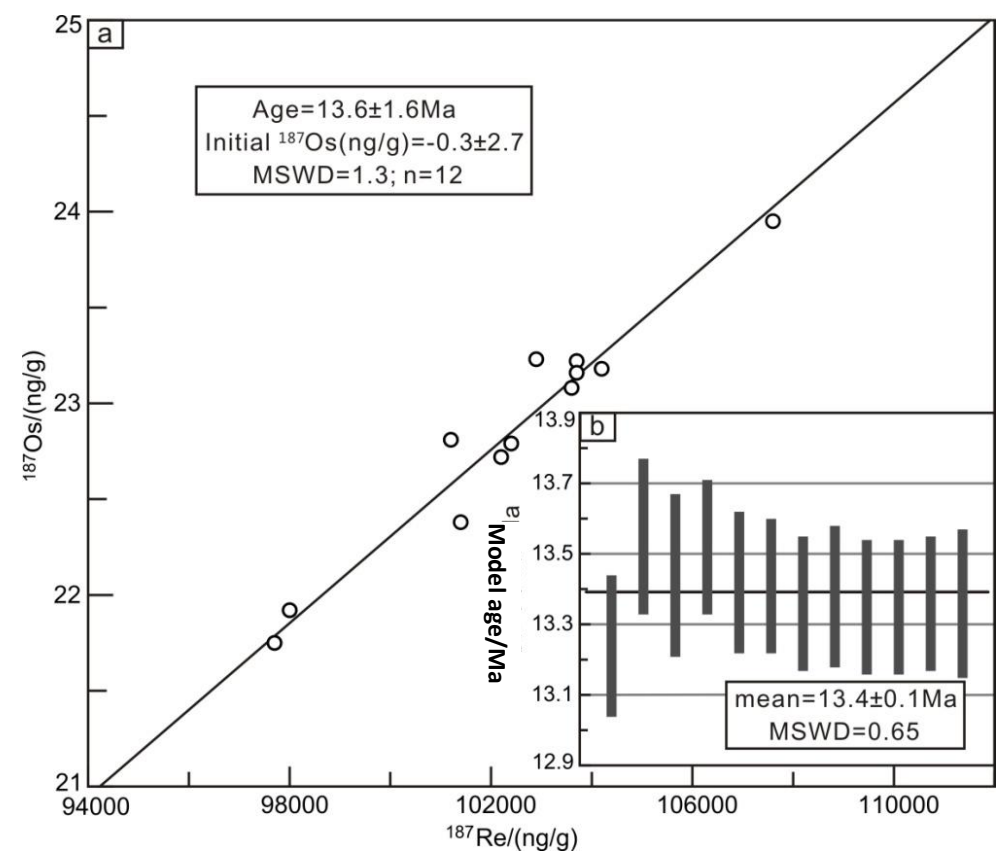

Fig.5 Re-Os isotopic isochron (a) and weighted mean model age (b) of molybdenite in Gangjiang deposit

\section{Conclusion}

(1) The LA-ICP-MS zircon U-Pb geochronology results present that the formation ages of monzonite granite porphyritic granite , porphyritic granodiorite and quartz-mica diorite are $16.6 \pm$ $0.3 \mathrm{Ma}, 16.1 \pm 0.2 \mathrm{Ma}$ and $14.4 \pm 0.4 \mathrm{Ma}$. Molybdenite Re-Os dating shows that Re-Os isochron age is $13.6+1.6 \mathrm{Ma}$ and the weighted average age is $13.4+0.1 \mathrm{Ma}$; which reveal the mineralization age of $\mathrm{Cu}-\mathrm{Mo}$ system. According to the combination of field geological investiage and LA-ICP-MS zircon U-Pb dating results, the magmatic intrusion sequence in the study area is as follows: ore-bearing monzonite granite porphyry $\rightarrow$ granodiorite porphyry $\rightarrow$ rhyolite porphyry (depth named as quartz-mica diorite porphyrite).

(2) the Gangjiang content changes of molybdenite Re copper molybdenum deposit in $155.4 \mathrm{ug} / \mathrm{g}$ $\sim 171.1 \mathrm{ug} / \mathrm{g}$, average $162.9 \mathrm{ug} / \mathrm{g}$, indicating the addition of mantle-derived components in ore-forming fluid.

(3) Mineralization age of the Gangjiang $\mathrm{Cu}-\mathrm{Mo}$ deposit is consistent with the age of other deposit at $(17 \sim 13 \mathrm{Ma})$ in the Gangdese metallogenic belt. Those deposit, including Gangjiang are formed in extensional environment of the post Indian-Asian collisional stage.

\section{Acknowledgements}

The Engineer Peipei Zhang and Guangwang Wang of Lhasa Tian Li Mining Co., Ltd. gave us a great help in the field work; Dr. Zhen Yang, Dr. Kai Sun and Master Lili Zhang of China University of Geosciences (Wuhan) participated in the field work. Dr. Peng Sha of Yunnancopper Australia Company puts forward a lot of constructive comments for the paper. The anonymous reviewers pointed out a number of shortcomings and put forward valuable suggestions for the revision of the paper in the process of peer review, in this together to extend the sincere thanks.

\section{References}

[1]Rui, Z. Y. , Li, G. M. , Zhang, L. S. , et al. , 2004. The Response of Porphyry Copper Deposits to Important Geological Events in Xizang. Earth Science Frontiers, 11(1): 145-152. 
[2] Leng, Q. F. , Tang, J. X. , Zheng, W. B. , et al. , 2015. Re-Os Dating of Molybdenite from the Lakange Porphyry $\mathrm{Cu}-\mathrm{Mo}$ Deposit in Tibet and Its Geological Significance.Geology in China, 42(2): 570-584 (in Chinese with English abstract).

[3] Zhang, Q. S. , Zheng, L. B., Wang, G. W. , et al. , 2012. Geological Characteristics of Gangjiang-Bairong Porphyry Cu-Mo Deposit in Tibet and Ore-Searching Directions.Contributions to Geology and Mineral Resources Research, 27(3): 300-307.

[4] Song, B. , Zhang, Y. H. , Wang, Y. S. , et al. , 2002. Mount Making and Procedure of the SHRIMP Dating. Geological Review, 48(Suppl. ): 26-30.

[5] Gao, S. , Liu, X. M. , Yuan, H. L. , et al. , 2002. Analysis of Forty-Two Major and Trace Elements of USGS and NIST SRM Glasses by LA-ICP-MS. GeostandardNewslett, 22: 181-196.

[6]Liu, X. M. , Gao, S. , Yuan, H. L., et al. , 2002. Analysis of 42 Major and Trace Elements in Glass Standard Reference Materials by 193 nm LA-ICP-MS. ActaPetrologicaSinica, 18(3): 408-418.

[7] Andersen, T. , 2002. Correction of Common Lead in U-Pb Analyses that Do not Report $204 \mathrm{~Pb}$. Chemical Geology, 192(1-2):59-79. doi: 10. 1016/s0009-2541(02)00195-X

[8] Ludwig, K. R. , 1999. A Geochronological Toolkit for Microsoft Excel.Geochronology Center, Berkeley.

[9]Hou, K. J. , Li, Y. H. , Tian, Y. R. , 2009. In Situ U-Pb Zircon Dating Using Laser Ablation-Multi Ion Counting-ICP-MS. Mineral Deposits, 28(4): 481-492.

[10]Fang, G. C. , Chen, Y. C. , Chen, Z. H. , et al. , 2014. Zircon U-Pb and Molybdenite Re-Os Geochronology of the Panggushan Tungsten Deposit in South Jiangxi Province and Its Significance. Acta Geoscientica Sinica, 35(1): 76-84. 